Meta

Journal des tradlucteurs

Translators' Journal

\title{
The Cross-temporal Factor in Verse Translation
}

\section{James S. Holmes}

Volume 17, numéro 2, juin 1972

URI : https://id.erudit.org/iderudit/003078ar

DOI : https://doi.org/10.7202/003078ar

Aller au sommaire du numéro

Éditeur(s)

Les Presses de l'Université de Montréal

ISSN

0026-0452 (imprimé)

1492-1421 (numérique)

Découvrir la revue

Citer cet article

Holmes, J. S. (1972). The Cross-temporal Factor in Verse Translation. Meta, 17(2), 102-110. https://doi.org/10.7202/003078ar d'utilisation que vous pouvez consulter en ligne.

https://apropos.erudit.org/fr/usagers/politique-dutilisation/ 


\section{The Cross-Temporal Factor in Verse Translation*}

Writers on translation (translation, that is to say, in the sense which Roman Jakobson has termed «interlingual translation ${ }^{1}$ 》) have usually tended to neglect the $\ll$ cross-temporal ${ }^{2} \gg$ factor in the process, abstracting it instead as a synchronic process in order to concentrate on problems that are no doubt more central. There is, however, a set of problems specific to translating a text that not only was written in another language but derives from another time, and it is perhaps worth our while to take a closer look at these problems of cross-temporal translation.

The formal model of translation as a communication process is well known. In simplified terms it is this. A person who can be called the source $(S)$ encodes a message (M) in a specific language (A) and transmits it to a receiver $\left(R_{\mathbf{A}}\right)$. This receiver, as translator, then performs a kind of « translingual transfer 》 $(\underset{\mathrm{TR}}{=})$ to encode in a second language (B) a new message $\left(M_{B}\right)$ that is intended to «mean the same as » or «correspond to message, or at any rate to give the illusion of doing some of these things ${ }^{3}$.

* Revised text of a paper presented at Nitra, Slovakia, in September 1969. The papers read at the conference are now being prepared for publication in English under the title Text and Context, ed. František Miko and James S. Holmes.

1. Roman Jakobson, "On Linguistic Aspects of Translation », in On Translation, ed. Reuben A. Brower, Cambridge (Mass.), Harvard University Press, 1959, p. 232-239, see p. 233.

2. I have preferred the term "cross-temporal " to " diachronic " for two reasons : i) " diachronic " has come to be used primarily in regard to languages to the exclusion of other systems viewed in a temporal perspective, and 2) even within the linguistic context it tends to refer to developments over a range in time rather than the kind of contrastive study of two états de langue that is involved in the cross-temporal translation process.

3. That the new message should " mean the same " as the original message is, of course, the popular conception; that it should \& correspond to * or \& be equivalent to " it is the point of view advanced by Eugene E. Nida, J. C. Catford, and other prominent theorists of translation. The creating of an "illusion » of equivalence is, $I$ should suggest, a factor of greater importance, at least in literary translation, than has usually been recognized. On this point see also Jiři Levy, Die literarische Übersetzung : Theorie einer Kunstgattung, Frankfurt am Main \& Bonn, Athenäum Verlag, «Athenäum Bücher zur Dichtkunst », 1969, p. 31-32. 
Functioning as a new source $\left(\mathrm{S}_{\mathrm{B}}\right)$, the translator then transmits this new message to a new receiver $\left(R_{B}\right)$.

1) $S_{A} \rightarrow M_{A} \rightarrow R_{A} \underset{T R}{=}>S_{B} \rightarrow M_{B} \rightarrow R_{B}$

For many aspects of translation theory it is convenient to simplify this model to the formulation

2) $\mathrm{M}_{\mathrm{A}} \underset{\mathrm{TR}}{=}>\mathrm{M}_{\mathrm{B}}$

or, introducing the inelegant but standard terms «source language $\$$ (SL) and «target language » (TL), to

3) $\mathrm{M}_{\mathrm{SL}} \underset{\mathrm{TR}}{=}>\mathrm{M}_{\mathrm{TL}}$

In the case of verse translation the simplified model can be stated in terms of poem $(\mathrm{P})$ and metapoem $^{4} \gg(\mathrm{MP})$ :

4) $\mathrm{P}_{\mathrm{SL}} \underset{\mathrm{TR}}{=}>\mathrm{MP}_{\mathrm{TL}}$

Obviously in this last case, which might be termed the model of the « metapoetic process", much more is in reality involved in the transfer $\underset{\mathrm{TR}}{=}>$ than purely a shift from one linguistic system to another. Simultaneously there is a shift from what may be called, in the largest sense, the socio-cultural system within which the poet operated to the socio-cultural system of the metapoet; and on a more restricted level there is a shift from the literary or poetic system ${ }^{5}$ within which the poem has its place to the literary system in terms of which the metapoem must find expression. On each of these three levels, the general level of the socio-cultural system and the more specific levels of the linguistic and literary systems, the translator is faced by inter-system incompatibilities that he must resolve, or in any case deal with in such a way as to give the reader of the metapoem the illusion they have been resolved.

When the poem to be translated is a contemporary one, the translator can approach each of these pairs of systems synchronically, as if they were static systems, frozen in time. Actually, of course, they are in constant change, and the translator of a poem of another age cannot ignore this fact, which confronts him with a series of problems in which the cross-temporal factor may loom as large as the interlingual. Moreover it would appear that translators tend to deal with these cross-temporal problems in ways that are quite similar to the approaches of native speakers who are reading a non-contemporary poem. If this is true, the translator's solutions would seem to have a relevance beyond the field of translation studies alone.

4. For the term "metapoem " see my papers «Poem and Metapoem : Poetry from Dutch to English , Linguistica Antverpiensia (Antwerp), III (1969):101-115, and $\propto$ Forms of Verse Translation and the Translation of Verse Form ", in The Nature of Translation : Essays on the Theory and Practice of Literary Translation, ed. James S. Holmes with Frans de Haan and Anton Popoviě, The Hague and Paris, Mouton, and Bratislava, Pubblishing House of the Slovak Academy of Sciences, * Approaches to Translation Studies, $I \gg, 1970$, p. $91-105$.

5. I use this term to indicate the entire system of literary and (more specifically) poetic conventions within which (or in revolt against which) a poem is written. In this brief paper it has been convenient to focus attention on such surface patterns as rhythm, metre, and rhyme and their function within the poetic system, but the term is intended to include more complex patterns and relationships as well. 
Let me turn to an examp'e. There is a rondel by Charles d'Orléans that runs like this :

Jeunes amoureux nouveaulx,

En la nouvelle saison,

Par les rues, sans raison,

Chevauchent faisans les saulx.

Et font sailler des carreaulx

Le feu, comme de charbon:

Jeunes amoureux nouveaulx

En la nouvelle saison.

Je ne sçay si leurs travaulx

Ilz employent bien ou non;

Mais piqués de l'esperon

Sont autant que leurs chevaulx,

Jeunes amoureux nouveaulx ${ }^{6}$.

Now clearly, for all the apparent simplicity of this poem, it is a highly intricate structure containing features that would not have been easy for a fifteenthcentury contemporary of Charles d'Orléans (or for that matter the Duke himself) ${ }^{\top}$ to render into English. These features are not our direct concern here, but I would call attention to the syllabic verse system (as opposed to the English accentual or accentual-syllabic); the sustained rhyme and the complex rondel form; the contrapuntal use of the word nouveaulx/nouvelle, occurring five times in all, and lending emphasis to the major theme of the poem; the general absence of adjectives other than nouveaulx/nouvelle (and the supporting jeunes - three occurrences), which serves to foreground ${ }^{8}$ these two words even more; the delay in complete explicitation of the major imagic element chevaulx until the penultimate line; and the shift from objective to subjective and from descriptive to commentative in the last stanza.

The translator of today, unlike his counterpart of the fifteenth century, cannot consider these features by themselves; he must relate them to a series of crosstemporal problems. These problems, too, are not solely linguistic, but also literary and socio-cultural. On the linguistic level, the translator must find a solution for

6. The text is cited here as it was given in the New Statesman competition (see below, n. 15). The standard text (to be found in Charles d'Orléans, Poésies, ed. Pierre Champion, 2 vol., Paris, Librairie ancienne Honoré Champion, 1923 and 1927, I, 247), has the following textual differences : 11. 1, 5, 13 read Jennes for Jeunes; 1.6 read cherbon for charbon; 1. 10 read emploient for employent. In 11. 7, 8, and 13 square brackets are used to indicate the words not written out in the manuscript but obviously meant to be repeated. Three valuable recent studies to deal at length with the fifteenth-century poet and his verse are Norma L. Goodrich, Charles of Orleans : A Study of Themes in His French and in His English Poetry, Geneva, Droz, 1967; Daniel Poirion, le Lexique de Charles d'Orléans dans les ballades, Geneva, Droz, 1967 ; and John Fox, The Lyric Poetry of Charles d'Orléans, Oxford, Clarendon Press, 1969.

7. The texts of Charles' poems in English, written during the quarter century of imprisonment after his capture at Agincourt, were edited by Robert Steele for the Early English Text Society (vol. 215 and 220) as The English Poems of Charles d'Orléans, 2 vol., London, Oxford University Press, 1941 and 1946. For a discussion of the English verse, see the book by Norma Goodrich referred to in n. 6 .

8. The term introduced by Paul L. Garvin as a translation of the Czech aktualisace. See his A Prague School Reader on Esthetics, Literary Structure, and Style, Washington (D.C.), Washington Linguistic Club, 1958. 
the fact that the poem is written in an older état de langue or «temporal dialect ${ }^{9} »$ : should he reflect this in some way in his translation, and if so, how ? On the literary or poetic level he must for instance consider what is to be done with the rondel form - in Charles d'Orléans' time a lively, much-used verse form, and actually one of the least complex of the forms of the day; now a relic of a bygone poetic tradition felt to be more appropriate for a jeu d'esprit than for serious verse. And on the socio-cultural level the translator must face up to the fact that the central image of the poem, young men riding on horseback to impress the girls, has lost its compelling force : their counterparts today ride motor-bikes or drive cars. (Similarly the subsidiary metaphor of sparks from charcoal, then a reference to a familiar, everyday event, is now a "literary» reference remote from life.)

In all such instances, and on each of the various levels, the translator must make a choice. The choice in each individual case may be to attempt to retain the specific aspect of the original poem, even though that aspect is now experienced as historical rather than as directly relevant today; this approach might be called 《historicizing translation» or « retentive translation». Or the choice may be to seek « equivalents» (which are, of course, always equivalent only to a greater or lesser degree) to " re-create» a contemporary relevance, an approach that could be called "modernizing translation $»$ or " re-creative translation ${ }^{10} »$.

Actually, this bipolar model of « historicizing 》 $(\mathrm{H})$ versus « modernizing » (M) or \& retentive» versus « re-creative» is rather more stylized than reality. On the linguistic level, for instance, there is not solely a choice between translating Charles d'Orléans' poem into fifteenth-century English or the English of today. Theoretically, in fact, there is a whole range of possible choices. For practical purposes, though, the target literary system dictates one of three ${ }^{11}$ : 1) The poem is rendered in a replica of fifteenth-century English ; 2) The poem is rendered in a variety of what Geoffrey Leech has called «standard archaic usage ${ }^{12} »$, the poetic idiom created round the time of Shakespeare and Spenser and used with greater or lesser modifications till early in the present century; 3) The poem is rendered in a modern poetic idiom, an idiom that might be characterized by its willingness to integrate almost any linguistic material but standard archaic usage ${ }^{13}$. (This third idiom must in turn be divided into two sub-varieties, "early» or «traditional» modern and « experimental modern»

9. The term used e.g. by John C. Catford : see his A Linguistic Theory of Translation : An Essay in Applied Linguistics, London, Oxford University Press, "Language and Language Learning, V III $n, 1965$.

10. The two terms " retentive translation s and "re-creative translation", unlike the other pair, have a broader relevance than in the cross-temporal situation alone, and might be roughly equated with Eugene $\mathbf{E}$. Nida's * formal-equivalence translation " and « dynamicequivalence translation 》 : see his Toward a Science of Translating, with Special Reference to Principles and Procedures Involved in Bible Translating, Leiden, Brill, 1964, p. 159-160, 165-177. The term «modernizing translation » has an ancestor in the concept of "modernization " or "Anglicizing " applied in the seventeenth and eighteenth centuries to English translations of the classics.

11. Or, for certain specific purposes (to achieve irony, for instance), a combination of them

12. Geoffrey N. Leech, A Linguistic Guide to English Poetry, London, Longmans, "English I anguage Series ", 1969 , p. 13. Leech bases his definition of this style on the detailed studies of B. Groom, The Diction of Poetry from Spenser to Bridges, Toronto, 1955.

13. Except when that can be used for facetious or ironic purposes. 
or «contemporary», both of which are acceptable to large groups of poetry readers today ${ }^{14}$.) The first of these three choices, rendering in the language of the author's day, might be labelled $\mathrm{H}$, while later non-modern choices might be indicated as $\mathrm{H}_{1}, \mathrm{H}_{2}, \mathrm{H}_{3} \ldots \mathrm{H}_{\mathrm{n}}$, and the choice of modern idiom $\mathrm{M}$ (with a sub-distinction $\mathrm{M}_{1}$ for «traditional modern » and $\mathrm{M}_{2}$ for « contemporary »).

With these remarks in mind, it is worth our while to look briefly at four recent translations of the rondel Jeunes amoureux nouveaulx. All these translations are contemporary : they were, in fact, all published for the first time only a few years ago. None of them is by a poet or translator of renown (actually they are the winning submissions in a «weekend competition » set by the New Statesman in March 1969) ${ }^{15}$, but they serve to illustrate some of the points I am attempting to make.

The first of the versions, by Adam Khan, is clearly historicizing in its overall approach. The language presents itself as medieval (out of 55 lexical items there are 32 , constituting 25 different words, that are identifiable as belonging to the temporal dialect of Middle English), and more particularly as the language of the anonymous lyrics of the English fourteenth and fifteenth centuries. Prosodically, the translation is « mimetic » in preserving the rondel form, « historicizing analogical ${ }^{16} »$ in substituting accentual verse with a varying number of syllables and feet (the verse pattern of the anonymous lyrics) for the syllabic verse of the French, with its strict adherence to seven syllables per line. (In Charles d'Orléans' own translations of rondels into English he preferred a quite regular accentual-syllabic line of ten syllables, a more courtly, less popular verse form.) As might be expected in a translation that is historicizing in both its linguistic and its literary approach, the socio-cultural situation of the original has been retained as well.

Lusty yonge bacheleres,

In the Spring sesoun,

Ryden the stretes sans resoun,

Making to-lepen hir coursers.

And strykken al-over.

Fyr fro everich stoon:

Lusty yonge bacheleres

In the Spring sesoun.

I noot nat yif hir labours

Been to gode or il chosen;

But prikke of spore felen

Even as doon hir coursers,

Lusty yonge bacheleres.

If the general approach of a translator to the cross-temporal factors (D) involved in a translation can be considered as a set, and if his approach to the

14. Though there are indications that the "early modern " idiom is being experienced by a growing number of readers of poetry as historical.

15. Competition $N^{\circ} 2,039$, set by Ann Arbor, results reported in the New Statesman for 11 April 1969.

16. On the terms « mimetic and « analogical " see the second paper mentioned in $n .4$. 
cross-temporal aspects of the linguistic (1), literary or poetic (p), and sociocultural (s) systems reflected in the poem can be posited as the three items in that set

5) $\mathrm{D}(1, \mathrm{p}, \mathrm{s})$

then the approach of this translator must be qualified as $(\mathrm{H}, \mathrm{H}, \mathrm{H})$. Mr. Khan's metapoem, like the original, comes to the present-day English reader through the haze of history, and it confronts the reader in English with much the same kinds of interpretative problems as does one of Charles d'Orléans' own English poems.

In the translation by Gavin Ewart the emphasis is quite different. The horse-riding theme is retained, and as a result there is little in the lexical items taken individually to mark them as specifically of the twentieth century, but nevertheless the general effect of the poem is decidedly contemporary. This is to a large degree the result of formal decisions. The amphibrachic metre and the exclusively feminine rhymes, both of them unusual in English, in conjunction lend a drive to the verse that underscores the poem's theme in an unusual fashion. The variation of the two opening lines in lines seven and eight (instead of the full repetition required by the rondel form) serves to foreground the form of the original by means of what Jiř̂́ Levý has termed "anti-style ${ }^{17}$ 》 - a technique which is quite probably one of the distinguishing features of contemporary poetry. This translator's approach can be qualified as $\left(\mathrm{M}_{2}, \mathrm{M}_{2}, \mathrm{H}\right)$.

\section{Young lovers beginning \\ begin a new season, \\ fill streets with unreason, \\ ride around, spinning,}

bright sparks on paving

like fires in the autumn :

young lovers behaving

like mares in their season.

I don't know if they're sinning

against Time, or erring;

but under Love's spurring

they're horses - and winning, young lovers beginning.

A translation by Peter Rowlett is, aside from one feature, demonstrative of an approach to cross-temporal translation that is more usual than either Mr. Ewart's or Mr. Khan's. Retaining the socio-cultural situation of the original, Mr. Rowlett has written an English «metapoem » that is "traditional modern》 in lexis and syntax, and prosodically in a form that is compatible with either traditional-modern or standard archaic usage. (The one exceptional feature lies in the word «prick», which is introduced as synonymous with «spur », but in the context very clearly has the meaning of «penis 》 as well. In the second sense out of place in a poetic text in any idiom except the contemporary, the

17. In his " Mathematical Aspects of the Theory of Verse », in Statistics and Style, ed. Lubomír Doležel and Richard W. Bailey, New York, American Elsevier, "Mathematical Linguistics and Automatic Language Processing, VI», 1969, p. 95-112. 
word is introduced here with singular effect to organize and explicitize the central metaphor of the poem, but at the same time it lends an ironic dimension to the traditional-modern idiom and traditional form that in a way resembles the tension between courtly form and meditative content that has been detected in Charles d'Orléans' own later verse.) Mr. Rowlett's approach might be qualified as $\left(\mathrm{M}_{1(2)}, \mathrm{M}_{1} / \mathrm{H}, \mathrm{H}\right){ }^{18}$.

Hot young lovers, season-sick,

Burning with the year's advance

Roam the restless streets of France;

As their stallions wheel and kick

The flinty cobbles sharp and quick

The sparks fly like a fiery lance.

Hot young lovers, season-sick,

Burning with the year's advance.

God knows what makes the youngsters tick

Or even if they like the dance...

The spur's what makes the stallion prance:

They too are governed by the prick.

Hot young lovers, season-sick.

Another translation, by G. R. Nicholson, contains one major feature that distinguishes it strikingly from the others. This is the contemporization of the socio-cultural system, that is to say, the updating of the theme from horsebackriding swains to motorcycle-riding « rockers». Paralleling this feature is a contemporization of lexis : five different words (ten lexical items) date from within the past twenty years in the sense in which they are used in the metapoem, and several others are typically twentieth-century. The verse form, by contrast, is at best traditional-modern, and so functionally is in marked irony to the «with-it» tone of the idiom. The approach in this version might be qualified as $\left(\mathrm{M}_{2}, \mathrm{M}_{1} / \mathrm{H}, \mathrm{M}\right)^{19}$.

18. In the case of this and the next translation it seemed appropriate to break down the approach to the literary systems into two sub-aspects : the approach to the general problem of verse form (here qualified $\mathrm{M}_{1}$ ) and the approach to the more specific problem of what to do with the rondel form as such (here $\mathrm{H}$ ). Inclusion of other more complex aspects of the literary system in the analysis would no doubt lead to a more clearly delineated profile of the translator's approach than it has been possible to define here.

19. Form and idiom support each other more harmoniously in another rendering by $\mathbf{M r}$. Nicholson, in which a verse system very similar to that in the translation quoted above is fused with a lexis and syntax that border on the standard archaic :

Young lovers with new love aglow,

In the springtime of the year,

Through the streets in wild career

On their prancing horses go.

Their horseshoes from the flagstones throw,

Fire that like sparks from coals appear:

Young lovers with new love aglow

In the springtime of the year.

What profit their love's labours show

I know not, not what loss they bear;

Under the spur their horses rear

But they a spur more mordant know,

Young lovers with new love aglow.

The two translations were submitted to the New Statesman as a pair, and $\mathbf{I}$ am probably doing Mr. Nicholson less than justice by dealing with one of them in isolation. 
Young rockers with a bird in tow,

Now the long evenings are here,

Reviving their engines, changing gear,

$U p$ and down the streets they go.

They do a ton-up, just for show, Along a stretch not far from here : Young rockers with a bird in tow

Now the long evenings are here.

Whether they're having it or no

I'm left to wonder, but it's clear

The engine's music in their ear

Speaks for the urge that works them so,

Young rockers with a bird in tow.

Put in the form of a table, the approaches of the four translators can be classified as follows :

\begin{tabular}{lllll}
\hline & \multicolumn{4}{c}{ System } \\
\cline { 2 - 5 } Translator & Linguistic & \multicolumn{2}{c}{ Literary 1} \\
Verse & (General) & $\begin{array}{c}\text { Rondel } \\
\text { Form }\end{array}$ & Socio-Cultural \\
\hline Khan & $\mathrm{H}$ & $\mathrm{H}$ & $\mathrm{H}$ & $\mathrm{H}$ \\
Ewart & $\mathrm{M}_{2}$ & $\mathrm{M}_{2}$ & $\mathrm{M}_{2}$ & $\mathrm{H}$ \\
Rowlett & $\mathrm{M}_{1(2)}$ & $\mathrm{M}_{1}$ & $\mathrm{H}$ & $\mathrm{H}$ \\
Nicholson & $\mathrm{M}_{2}$ & $\mathrm{M}_{1}$ & $\mathrm{H}$ & $\mathrm{M}$ \\
\hline
\end{tabular}

1 Here broken down into the two sub-aspects introduced above : see n. 18 .

Two things strike the eye in this table. First there is the fact that of the four translations only Mr. Khan's is of one piece, the others combining a historicizing approach at one level with a modernizing at another, and none of them modernized at all levels. A cursory examination of other translations of older poetry into and from various languages led to findings which support this analysis. There would seem to be particular resistance to transposing a poem of another day into a metapoem that is completely modern on all levels, with nothing in it to indicate its ties with an earlier time. If this hypothesis is correct, it means that the inclination to classify translations as modernizing or historicizing from an overall point of view must be abandoned in favour of a more elaborate analysis establishing a more complex profile for each translation.

It may very well be that once that is done on a larger scale, and in more detail than it has been possible to do here, we shall also discover that the pressures towards (and the resistance to) either modernizing or historicizing are different in regard to each of the various systems. This leads me to a second point to be detected from the table. If one is to judge from these four translations, there would seem to be particular resistance to modernizing in the socio-cultural sphere. Can it be said that the possibilities for re-creation rather than retention are more restricted in this sphere than in the linguistic and the literary, whereas in the other two spheres the pressures against retentive historicizing are greater? And have these possibilities and pressures varied from age to age and from country to country? 
These are questions that come to the fore as a result of this preliminary study, but for anything more than a highly provisional answer to them a more complex analytical method needs to be developed. In developing that method the translation analyst will have to rely first and foremost on the techniques and findings of contemporary literary and linguistic research. But at the same time he will have to evolve his own terms and techniques, adapted to the problems specific to his field of study. This paper is intended as a step in that direction.

JAMES S. HoLmeS 